\title{
Exchange Transfusion as Treatment for Rasburicase Induced Methemoglobinemia in a Glucose-6-Phosphate Dehydrogenase Deficient Patient
}

To the Editor: A recent letter in this journal described methemoglobinemia and hemolysis due to rasburicase in a patient with glucose-6-phosphate dehydrogenase (G6PD) deficiency [1]. We would like to report on the management of a patient with rasburicase induced methemoglobinemia and G6PD deficiency. DS is a 12-year-old Laotian male who presented with a white blood cell count of $533,900 / \mathrm{mm}^{3}$ (89\% blasts), hemoglobin $10.1 \mathrm{mg} / \mathrm{dL}$, and platelets of $27,000 / \mathrm{mm}^{3}$ and was diagnosed with T-cell Acute Lymphoblastic Leukemia. Metabolic labs were normal except BUN $23 \mathrm{mg} / \mathrm{dL}$, LDH 4,698 mg/dL, and uric acid $22.1 \mathrm{mg} / \mathrm{dL}$. Rasburicase (Elitek $\left.{ }^{\mathrm{TM}}\right) 10.5 \mathrm{mg}(0.2 \mathrm{mg} / \mathrm{kg})$ was administered. One hour later his uric acid was $18.1 \mathrm{mg} / \mathrm{dL}$, and $10 \mathrm{hr}$ later it was $<0.2 \mathrm{mg} / \mathrm{dL}$. During leukopheresis, his oxygen saturation level dropped to the $70 \mathrm{~s}$ and did not improve with supplemental oxygen. Methemoglobin levels were found to be $7-10 \%$. He received two doses of methylene blue, and a repeat methemoglobin level was $7 \%$ with persistently low oxygen saturation. A G6PD assay showed activity of $3 \mathrm{U} / \mathrm{gm}$ $\mathrm{Hgb}$ (normal 4.6-13.5 U/gm Hgb). He underwent a double-volume exchange transfusion, after which his methemoglobin level was $0 \%$ and his oxygen saturation was normal. Both remained normal throughout the remainder of his induction therapy.

Methemoglobin is generated when hemoglobin iron is oxidized from the ferrous $\left(\mathrm{Fe}^{2+}\right)$ to the ferric $\left(\mathrm{Fe}^{3+}\right)$ state. Administered methylene blue is converted to leukomethylene blue by the NADPH-dependent methemoglobin reductase system, which then transfers an electron to ferric iron reducing it to ferrous iron [2]. As evidenced in our patient, this mechanism is ineffective in G6PDdeficient patients because of the inability to generate sufficient NADPH to drive the reaction [2,3]. Therefore, the only effective treatment is direct removal of the methemoglobin by exchange transfusion [4]. In our patient, this treatment was successful in lowering his methemoglobin level and resolving his hypoxia.

Rasburicase has been reported to cause methemoglobinemia and hemolysis [1]. The package insert contains a recommendation for screening high-risk patients for G6PD deficiency prior to initiating rasburicase. However, in clinically emergent cases involving severe hyperuricemia and impending renal damage, waiting for a G6PD assay is usually not practical. Therefore, in patients at high risk for G6PD deficiency, we advocate close monitoring for hypoxia and methemoglobinemia when administering rasburicase. If the patient becomes hypoxic due to methemoglobinemia, avoid the use of methylene blue as this may precipitate a hemolytic anemia in a G6PD deficient patient while not treating the methemoglobinemia. Instead exchange transfusion is needed to remove the methemoglobinemia and improve oxygen saturations.

Priya Bhat, MD Department of Pediatrics University of Michigan Health Services Ann Arbor, Michigan

India Sisler, MD Anderson B. Collier III, MD* Department of Pediatrics Vanderbilt University Medical Center Nashville, Tennessee 37232

\section{REFERENCES}

1. Borinstein SC, Xu M, Hawkins DS. Methemoglobinemia and, hemolytic anemia caused by rasburicase administration in a newly diagnosed child with Burkitt lymphoma/leukemia. Pediatr Blood Cancer 2008:50:189.

2. Mansouri A, Lurie AA. Concise review: Methemoglobinemia. Am J Hematol 1993;42:7-712.

3. Rosen PJ, Johnson C, McGehee WG, et al. Failure of methylene blue treatment in toxic methemoglobinemia. Association with glucose-6phosphate dehydrogenase deficiency. Ann Intern Med 1971;75: $83-86$.

4. Golden PJ, Weinstein R. Treatment of high-risk, refractory acquired methemoglobinemia with automated red blood cell exchange. J Clin Apheresis 1998;13:28-31.

\footnotetext{
*Correspondence to: Anderson B. Collier, III, Pediatric Hematology Oncology, Vanderbilt University Medical Center, 2220 Pierce Ave, 397 PRB, Nashville, TN 37232-6310.

E-mail: anderson.b.collier@vanderbilt.edu
}

Received 30 January 2008; Accepted 7 March 2008 